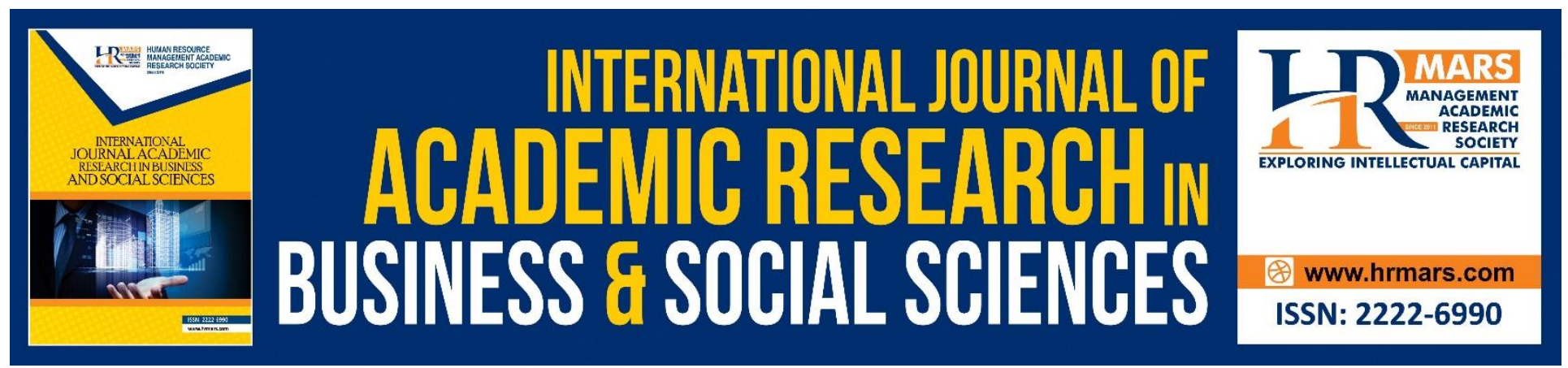

\title{
Digital Content Model of Social Study Education in User Generated Content Platform as A Media Literacy to Educate Students and Cyber Society
}

Feri Sulianta, Sapriya, Nana Supriatna, Disman

To Link this Article: http://dx.doi.org/10.6007/IJARBSS/v10-i8/7716

DOI:10.6007/IJARBSS/v10-i8/7716

Received: 15 May 2020, Revised: 04 June 2020, Accepted: 20 July 2020

Published Online: 16 August 2020

In-Text Citation: (Sulianta, Sapriya, Supriatna, Disman, 2020)

To Cite this Article: Sulianta, F., Sapriya., Supriatna, N., Disman., (2020). Digital Content Model of Social Study Education in User Generated Content Platform as A Media Literacy to Educate Students and Cyber Society. International Journal of Academic Research in Business and Social Sciences. 10(8), 1084-1092.

Copyright: (C) 2020 The Author(s)

Published by Human Resource Management Academic Research Society (www.hrmars.com)

This article is published under the Creative Commons Attribution (CC BY 4.0) license. Anyone may reproduce, distribute, translate and create derivative works of this article (for both commercial and non-commercial purposes), subject to full attribution to the original publication and authors. The full terms of this license may be seen

at: http://creativecommons.org/licences/by/4.0/legalcode

Vol. 10, No. 8, 2020, Pg. 1084 - 1092

http://hrmars.com/index.php/pages/detail/IJARBSS

JOURNAL HOMEPAGE

Full Terms \& Conditions of access and use can be found at http://hrmars.com/index.php/pages/detail/publication-ethics 


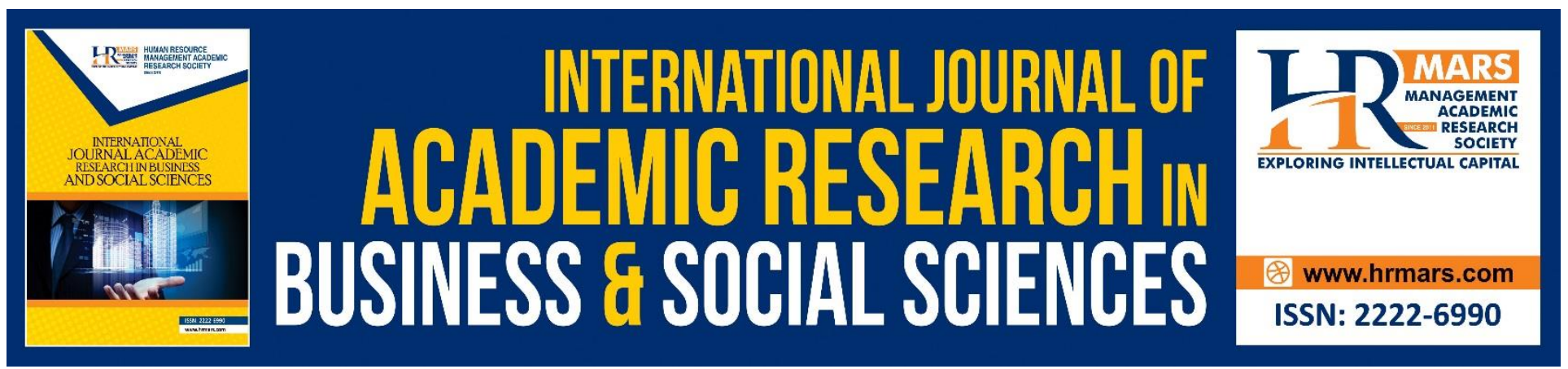

\title{
Digital Content Model of Social Study Education in User Generated Content Platform as A Media Literacy to Educate Students and Cyber Society
}

\author{
Feri Sulianta ${ }^{1}$, Sapriya $^{2}$, Nana Supriatna ${ }^{3}$, Disman $^{4}$ \\ ${ }^{1}$ School of Postgraduate Studies, Universitas Pendidikan Indonesia, Bandung, Indonesia, ${ }^{2}$ The \\ Department of Civic Education, Universitas Pendidikan Indonesia, Bandung, Indonesia, ${ }^{3}$ The \\ Department of Social Studies Education, Universitas Pendidikan Indonesia, Bandung,Indonesia \\ ${ }^{4}$ The Department of Economics Education, Universitas Pendidikan Indonesia, Bandung, Indonesia
}

\begin{abstract}
The amount of unuseful contents, such as hoaxes or false news, and non-educational content bring negative impact to the society, especially to the students. People who were influenced by hoaxes and non-educational digital content from the news and various digital contents, responded by writing negative comments on digital media. By utilizing digital literacy, it will contribute positive conduct in responding various digital content, for example being educated with positive content and contributing to the society by creating qualify digital content. Because of this reason, a digital content model contains social science education is needed as a media literacy to educate students and to digital society in general.

High quality of digital content has certain standards so that it will bring positive influence when it is distributed in digital media. Digital contents are not just the process of digitizing traditional content into digital media. Furthe more, various parameters of digital content, such as: Search Engine Optimization, writing mechanism, knowledge, social studies competency, digital media and digital copyright are part of the fundamental elements of qualify digital content models, which is built using transdisciplinary knowledge.
\end{abstract}

Keywords: Digital Literacy, Digital Society, Social Studies Competency, Digital Content, User Generated Content Platform

\section{Introduction}

Today's society can easily get digital content because of the influence of the internet, which is the product of computer and telecommunications technology. In this case, the internet is a tool that brings the world to the industrial age version 4.0. Today's society is targeted of the abundant content. Toffler (1970) in his book Future Shock describes technological and structural changes in society and popularizes the term information load. The society consumes contents that does not contribute to 
INTERNATIONAL JOURNAL OF ACADEMIC RESEARCH IN BUSINESS AND SOCIAL SCIENCES Vol. 10, No. 8, 2020, E-ISSN: 2222-6990 @ 2020 HRMARS

the growth of a good citizen. The digital content that is not qualified as good contents have several characteristics as follow: false news or hoaxes, untrustworthy content, the contents that is not userfriendly, the contents that do not support the right content visibility, etc.

The existence of negative digital content in Indonesia should be addressed carefully, it is because of the growth of the internet user in Indonesia. According to the results of research conducted by the Indonesian Internet Service Providers Association (APJII, 2017) collaborates with the University of Indonesia's Communication Studies Center (Puskakom) said that Indonesia is one of the countries with the largest number of internet users in the world, with the total the number of Internet users in Indonesia at the beginning of 2015 was 88.1 million people. And in 2016, there was a rapid growth of Internet users, which reach 132.7 million users. The growth of internet users in Indonesia is up to $51 \%$ for only a year.

\section{The Digital Society in Indonesia}

The development of the digital world is being able to contribute positively, on the other hand can also bring negative impact, therefore the development of digital technology including information accessibility must be anticipated wisely. Moreover, it is alleged that the young generation who access the internet is approximately 70 million people, which is quite high. These young people basically spend as much as 5 hours per day using the internet, either through mobile devices such as cell phones, or other devices such as personal computers, or laptops. In Indonesia the problem with developing digital technology and digital content shows approximately 25 thousand people access pornographic materials per day on average reaching 25 thousand people. Based on Mafindo's research during July to September 2018, there were 230 hoaxes with various content. Furthermore, the number of online media in Indonesia is quite high, which reaching 43,0400 per year in 2017 as reported by the chairman of the National Press Council, those which categorized as professional media are only $0.04 \%$.

\section{Industrial Age Version 4.0}

Industry 4.0 basically refers to automation and data exchange procedures that involve cyber systems, the internet of thing, cloud computing, and cognitive computing, each element is integrated intelligently. Through the Internet of Things (IoT), the cyber-physical system communicates and collaborates with each other and humans simultaneously. Through cloud computing, internal and cross-organizational services are provided and utilized by various parties in the production value chain. In this case, the exchange of information and production refers to digital content, also involving human intervention with an understanding of digital literacy that enables content creator to create information and in the other hand, they become consumer of digital information.

\section{Digital Literacy}

Along with the growth of Internet users and the ease of internet access in Indonesia should be addressed wisely. All those technology resources should be utilized to develop literacy skills. The internet enables anyone to produce useful content, such as by offering free services to create a personal blog. People need to understand that digital literacy is an important thing needed to give contribution in information age.

The availability of computers can raise digital literacy. The term digital literacy was popular in 2005 (Davis \& Shaw, 2011), digital literacy means the ability to relate to hyper textual information, 
nonsequential information accessibility using a computer. The term digital literacy was used in the 1980s (Davis \& Shaw, 2011), which means the ability to relate to hyper textual information by reading non-sequentially or not sequentially with the help of a computer (Bawden, 2001).

Digital literacy includes understanding web or website, as well as search engines. Users should be able to examine, not all information available on the web are trustworthy or qualify. The number of hoaxes distributed by the user is a fact that the community is not educated regarding digital literacy. It can be concluded that digital literacy is a group of an attitude, understanding the skills to handle and communicate information and knowledge effectively using various media and formats.

Digital media literacy considers the three components, such as: computing, communication networks and content that are packaged in digital format. Flew (2002) has an understanding that digital media is all forms of media content that combines and integrates data, text, sound and various kinds of images that are in digital format, and distributed through communication networks such as fiber optics, broadband, satellites and transmission systems microwaves.

According to Bawden (2008), the digital literacy component consists of four parts, as follows:

1. The main pillars:

a. Literacy

b. Computer literacy and information

c. Communication technology

2. The background knowledge is divided into:

a. Information

b. Nature of information resources

3. Core Competence:

a. Understanding of digital and non-digital formats

b. Creation and communication of digital information

c. Information evaluation

d. Knowledge assembly

e. Information literacy

f. Media literacy

4. $\quad$ Attitudes and way of thinking

Considine (2002) categorizes the objectives of media literacy education in the United States as, "protection, preparation and fun." Using a protectionist approach, media literacy education is the way to reduce risk of unethical behavior promoted by the media.

Preparation regarding media literacy refers to obtaining information and communication skills needed in citizenship and modern democratic society. And literacy activities allow students to find fun activities and become a means of critical appreciation of the media.

According to Mammonal Considine, media literacy education is related to various goals and objectives. Similarly, the process of the 1992 Aspen National Leadership Conference on Media Literacy, the founding document of the US media literacy movement, confirmed that teaching media literacy includes various emphases (Aufderheide \& Firestone, 1993).

The application of media literacy education articulates various reasons for media literacy education, and many in fact have strong disagreements about the main purpose (Hobbs, 1998b; Kubey, 2003). Learning from the literature in the field can be described and broadened with five main objectives for media literacy education in the United States, which are: protection from harmful media, health 
INTERNATIONAL JOURNAL OF ACADEMIC RESEARCH IN BUSINESS AND SOCIAL SCIENCES Vol. 10, No. 8, 2020, E-ISSN: 2222-6990 @ 2020 HRMARS

promotion and social development, citizenship and democracy, acquisition of tools for learning and self-expression and media enjoyment and appreciation as a form of creative art. All of them are related to social studies teachers and become the main objectives of research in the relationship of media literacy.

\section{Methodology}

In developing this digital content model, research using an Research and development (R\&D) approaches used to develop and validate educational products.

It is expected that the results of applicable research aimed to develop the quality of education and learning effectively and adaptably. The R \& D approach by Borg and Gall versions divided the stage by ten phases, which are seen in figure.1.

In the beginning of $R \& D$ research approach, a preliminary study was carried out reviewing the literature from previous studies and surveys regarding the importance of digital literacy in society in the industrial age version 4.0. Survey is done on educators, students and the community in general. The next stage is identifying related models that are needed to ascertain whether the model can solve the problem in the certain community or school.

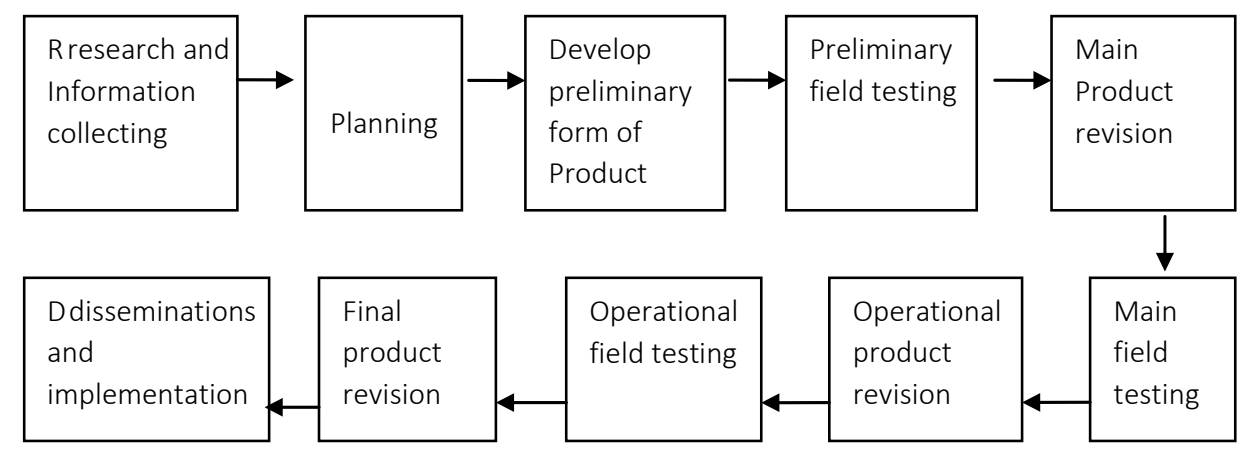

Figure 1. Model R\&D by Borg and Gall

The research planning phase, including formulating research objectives, and estimating the things needed in the study. In the initial product development stage, identify the facilities and infrastructure needed in the research, then create a model that will be developed, and determine the stages of design testing in the field. The field testing phase is limited (or: preliminary field test) to test the model, in this stage the testing scope is limited. Testing in the field is carried out several times in order to meet the appropriate design. Then, observation, interview and questionnaire are held to gather the information.

In early stage, the model is published in a limited educational environment, which is certain institutions in certain areas and certain educators. Whereas if the model is intended to be implemented in a wider scope, then several steps needed to be carried out are as follows: revision of limited field test results, broader field test (main field test), revised the results of a wider field test, feasibility test (operational field test). Then, final product revision is carried out when the model is to be applied to a wider environment, with diverse audiences, for example on the User Generated Platform portal.

The digital content model that aims to develop digital literacy is expected to be a counterweight and build public awareness of the importance of digital literacy, able and accustomed to critical thinking. 
INTERNATIONAL JOURNAL OF ACADEMIC RESEARCH IN BUSINESS AND SOCIAL SCIENCES Vol. 10, No. 8, 2020, E-ISSN: 2222-6990 ㄷ 2020 HRMARS

The digital content model must bring a virtue of industrial version 4.0, this is the goal of making digital content models.

\section{Digital Content Model}

The digital content model is a model to create the internet content, which involves many disciplines, and each of these disciplines is strongly interrelated, which involve interdisciplinary and some involving multidisciplinary, especially in connection with the goal of content that integrates knowledge with social studies. This is inline with Martin (2008) point of view, that digital literacy is a multi-dimensional skill. Understanding digital literacy is a step by step process, the next level is more complicated than the previous level. Digital competence requires the ability of computer literacy and technology.

Furthermore, people must master information, visual, media and communication literacy to be said to have digital literacy competencies. Riel, Christian \& Hinson (2012) also stated the same thing that digital literacy is multi-dimensional. But he explained that digital literacy is horizontal rather than vertical classification. However, digital literation in this study could be viewed as the ability use literacy skills whether is vertical or horizontal by using the digital content model as a framework (Sulianta, 2018).

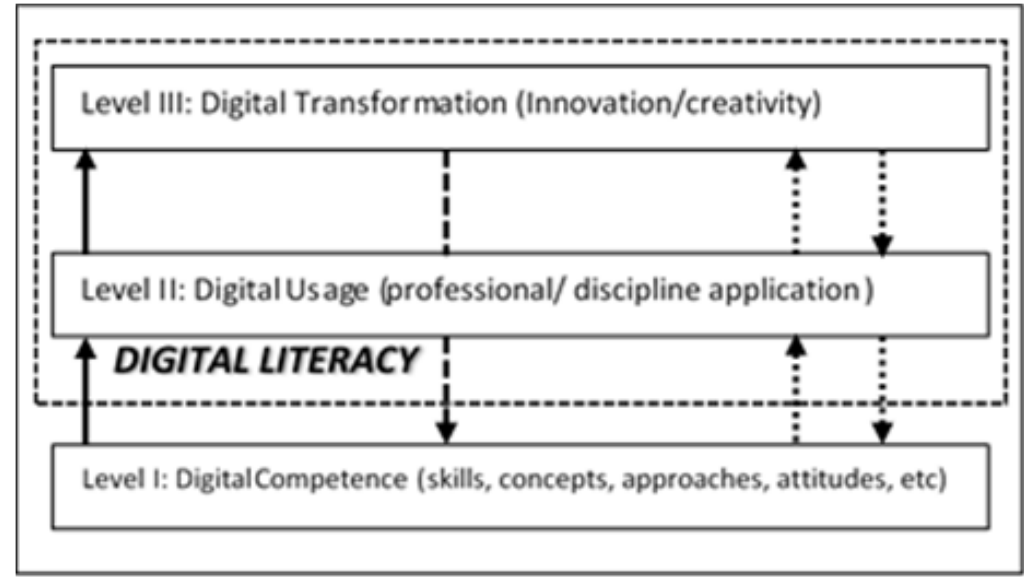

Figure 2. Digital literacy classification Source: Lankshear and Knobel (2008)

\section{Digital Content Writing Process}

Furthermore, regarding the standard of good writing, this requires skills and guidelines for writing, according to Tompkins and Hoskisson (1991) stated the five stages are prewriting, drafting, revising, editing, and publishing. This can be seen as a writing process consisting of five stages: (1) writing, (2) drafting, (3) revising, (4) editing, and (5) publishing.

Basically, in the process of writing digital content is not much different from the step of traditional writing. But in the broader perspective, there is lots of different because of the use of digital media. To produce the digital content, the creator requires skill of using information technology devices. The digital content is released on an Internet service or one of them is the User Generated Content Platform, so that the ability to use the internet play important roles.

The digital content is intended to be distributed in the User Generated Content Platform, so that the content creator must follow the rules of Search Engine Optimization (SEO) criteria. The digital content 
INTERNATIONAL JOURNAL OF ACADEMIC RESEARCH IN BUSINESS AND SOCIAL SCIENCES Vol. 10, No. 8, 2020, E-ISSN: 2222-6990 @ 2020 HRMARS

depended and it is influenced by another five main components such as: writing procedures, knowledge, social studies competency, digital media, digital copyright. Figure 3 shows a digital content model consist of 6 main components that are synergistically strongly related. The content development requires transdisciplinary knowledge which are: information technology, writing skills, social studies competency and knowledge integrating several disciplines that can create new understanding (synthesis). The models must be views as a whole. The creator should have an industrial version 4.0 skills. For example, he must understand Seach Engine Optimization technique, and how to apply digital media in User Generated Content Platform.

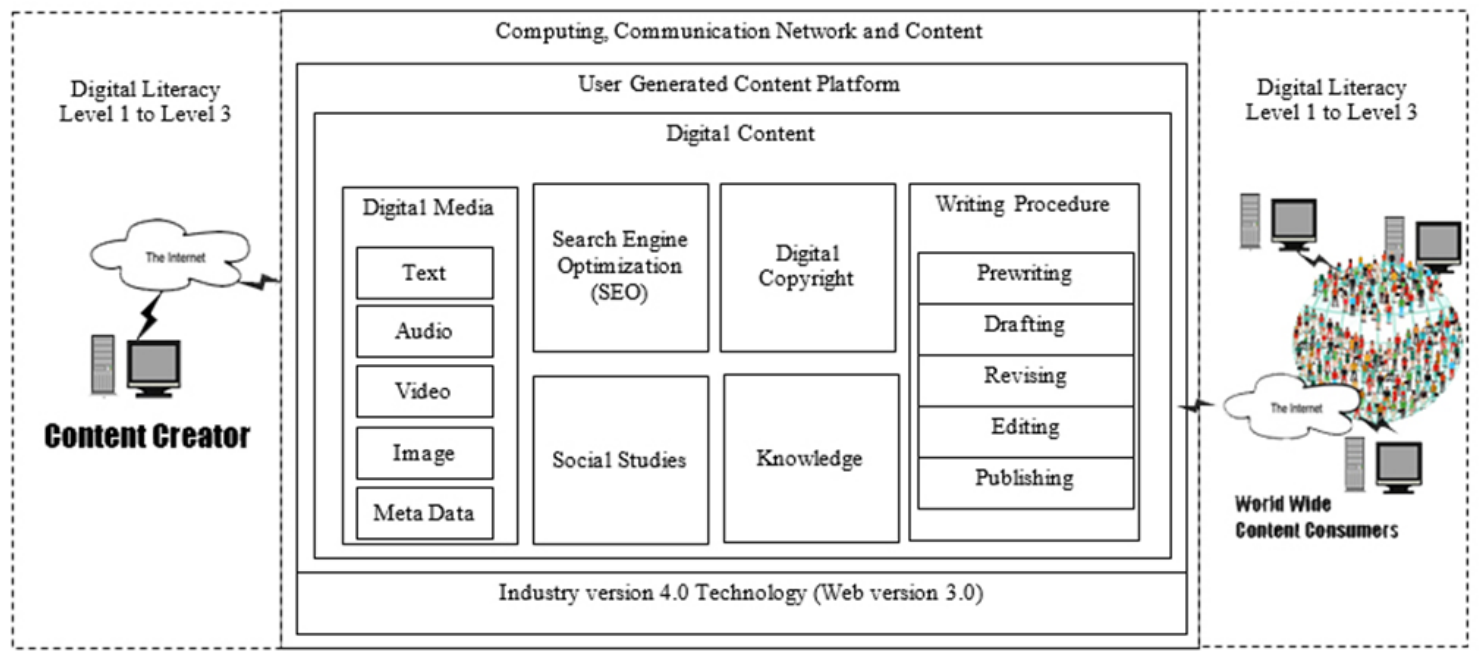

Figure 3. Model of a Digital Content

\section{Results}

The result of this study is a model of digital content in the perspective of social studies education which involves six components which are: knowledge with certain scientific backgrounds, Social Studies competency that provides content of social studies education, writing procedures that take into account digitalization schemes and technological considerations in disseminating, presenting, get and access it, and digital copyrights.

The model in this research was developed using the Research and Development method, which consist of five stages, such as: preliminary study, research planning, initial product development, limited field testing and limited revision results. Until this stage, the revisions made were restricted to the information technology factors, which would then be continued with implementation and testing the model in a broader scale later on. According the result, the model could be functioned well on a limited scale, which is limited to the educators and students. Assessment is implemented by gather questionnaires from the people who has role as content creator and content consumers. 
INTERNATIONAL JOURNAL OF ACADEMIC RESEARCH IN BUSINESS AND SOCIAL SCIENCES Vol. 10, No. 8, 2020, E-ISSN: 2222-6990 @ 2020 HRMARS

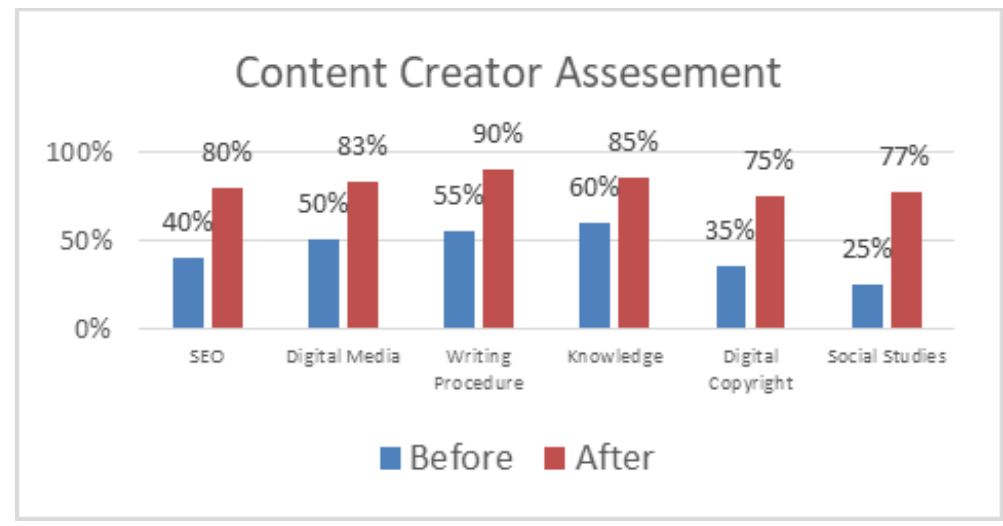

Figure 4. Content Creator Assessment

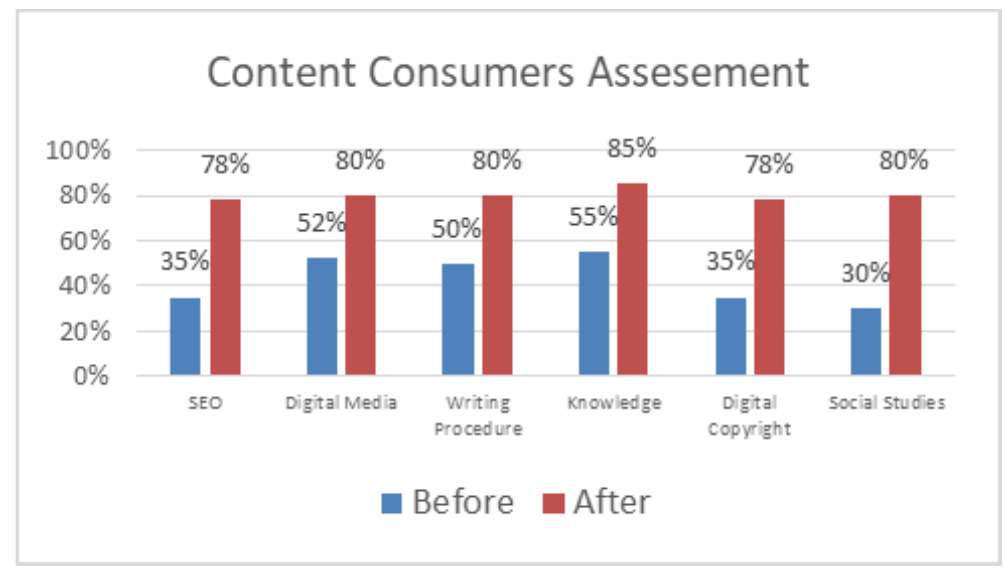

Figure 5. Content Consumers Assessment

Measurement of students is assessed regarding understanding six main elements of digital content, before and after learning digital content creation. In this measurement, students and educators have roles as content consumers and then the other side as content creators. The average score of creator content assessment, reached $82 \%$, which previous score assessment only reached $44 \%$. The average of consumer content assessment, preliminary measurements were similar to preliminary of content creator assessment, which reach $43 \%$, and the next average of content consumers assessment score reached $80 \%$. In this case the digital content model can be used to create quality digital content viewed from the perspective of consumers, while consumers apply digital literacy in analyzing quality digital content.

\section{Conclusion}

The development of computer and internet technology overwhelmed people with the negative content, which bring negative impact to the society. The negative content circulating such as hoaxes, unsuitable content or inappropriate content and content that lead to criminal actions. Despite the abundance of information resources and the development of technology in the industrial era version 4.0, not all people use all the virtue of the technology. For this reason, a model that can be used as a guideline to make useful content that has high visibility and quality also does not violate the rules of 
INTERNATIONAL JOURNAL OF ACADEMIC RESEARCH IN BUSINESS AND SOCIAL SCIENCES Vol. 10, No. 8, 2020, E-ISSN: 2222-6990 @ 2020 HRMARS

intellectual property rights, this is implemented in the digital community to support digital literacy. Models of digital content that involve users as well as creator content are expected to contribute to the quality of society in the industrial age version 4.0, which is a society that is knowledgeable, critical thinking approach and has good characters as a qualify citizen.

The digital content model of social studies is used as a guideline in creating quality digital content that considered six components, such as: SEO technique, writing procedures, social studies competency, digital media, digital copyright and knowledge. The benefits the content model can be used by educators as well as students and society regarding digital literacy. In the age industrial version 4, people who have good understanding of digital literacy can play good roles not only as consumers of digital content but as producers or creators of quality digital content.

\section{Acknowledgement}

This paper is a part of doctoral program. School of Postgraduate Studies Universitas Pendidikan Indonesia.

\section{Corresponding Author}

Feri Sulianta, School of Postgraduate Studies Universitas Pendidikan Indonesia. Indonesia.

Email: ferisulianta@upi.edu.my

\section{References}

Aufderheide, P., \& Firestone, C. M. (1993). Media literacy: a report of the National Leadership. In Conference on Media Literacy, the Aspen Institute Wye Center, Queenstown Maryland.

Bawden, D. (2001). Information and digital literacies: a review of concepts. Journal of documentation, 57(2), 218-259.

Considine, D. (2002). Putting the ME in media literacy. Middle Ground, 15-21.

Davis, C. H., \& Shaw, D. (Eds.). (2011). Introduction to information science and technology. American Society for Information Science and Technology.

Flew, T. (2002). Beyond ad hocery: defining creative industries. In Cultural Sites, Cultural Theory, Cultural Policy, The Second International Conference on Cultural Policy Research.

Hobbs, R. (1998). Building citizenship skills through media literacy education. The public voice in a democracy at risk, 57-76.

Kubey, R. W. (2003). Why US media education lags behind the rest of the English-speaking world. Television \& New Media, 4(4), 351-370.

Lankshear, C. J., \& Knobel, M. (2008). Introduction: Digital literacies: Concepts, policies and practices. Peter Lang Publishing.

Martin, A. (2008). Digital literacy and the "digital society". Digital literacies: Concepts, policies and practices, 30, 151-176.

Riel, J., Christian, S., \& Hinson, B. (2012). Charting digital literacy: A framework for information technology and digital skills education in the community college. Available at SSRN 2781161.

Sulianta, F. (2018). Panduan Lengkap Pengembangan Softskill Interpersonal dan Intrapersonal Skill. Yogyakarta: Andi Offset.

Toffler, A. (1970). The fractured family. Future Shock, New York: Random House, 211-30.

Tompkins, G. E., and K Hoskisson, K. (1991). Language Arts: Content and Teaching Strategies. New York: Max Well Macmillan Internationaal Publishing Group. 